\title{
Scion Shoot Removal and Rootstock Cultivar Affect Vigor and Early Yield of Grafted Tomatoes Grown in High Tunnels in the Central United States
}

\author{
Sarah A. Masterson ${ }^{1,4}$, Megan M. Kennelly ${ }^{2,5}$, Rhonda R. Janke ${ }^{1,6}$, \\ and Cary L. Rivard ${ }^{1,3,7,8}$
}

ADDITIONAL INDEX WORDs. hoophouse, heirloom tomato, organic, greenhouse tomato, propagation, splice grafting, tube grafting

SuMMARY. Grafting with interspecific hybrid rootstock is effective for tomato (Solanum lycopersicum) growers looking to reduce soilborne disease in the southeastern United States. However, production with grafted tomato has not been tested in the central United States, where soilborne disease pressure is low. Smallacreage growers would like to produce grafted plants themselves, but many have difficulty with propagation due to water stress in the scion postgrafting and/or high temperatures. Removing the upper portion of the scion to reduce leaf area during the grafting procedure [shoot removal (SR)] could help to reduce water stress postgrafting, but there are no data available that indicate what effect this practice has on tomato yield. Five high tunnel trials and one open-field trial were conducted in 2011 and 2012 to investigate potential yield effects related to the use of two rootstocks and SR during the grafting procedure. The implementation of grafting with rootstocks significantly increased fruit yield in five of the six trials $(P<$ $0.05)$. The average yield increases by 'Maxifort' and 'Trooper Lite' tomato rootstocks were $53 \%$ and $51 \%$, respectively, across all trials. SR during the grafting process may penalize tomato yield and our results suggest that rootstock vigor plays a role. Plants grafted with 'Maxifort' across all of the trials consistently increased shoot biomass in four of five of the high tunnel trials compared with nongrafted plants $(P<0.05)$, whereas plants grafted with 'Trooper Lite' rootstock increased shoot biomass in one trial. Similarly, the SR method penalized the total fruit yield of plants grafted with 'Trooper Lite' more often than those that were grafted with 'Maxifort'. Our results suggest that plant growth and ultimately tomato fruit yield is affected negatively by using the SR grafting technique, particularly when less vigorous rootstock is used.

$\mathrm{M}$ any small-acreage and/or organic vegetable growers in the United States are implementing high tunnels as a way to reduce foliar disease and extend the growing season (Carey et al., 2009; O'Connell et al., 2012). In particular, tomato is a popular crop for high tunnels and production in the central United States is increasing (Carey et al., 2009). Not only do high tunnels extend the growing season (Hunter et al., 2010; Wells and Loy, 1993), they also increase yield, economic return, and marketing opportunities (O'Connell et al., 2012; Wells, 1991). High producer interest, general affordability, as well as availability of federally funded cost-share programs (U.S. Department of Agriculture, 2013) have resulted in a dramatic increase in the amount of growers using high tunnels for vegetable crops and tomato in particular (Carey et al., 2009).
One challenge of managing high tunnel production systems is limiting soilborne diseases such as root-knot nematode (RKN; Meloidogyne sp.), southern blight (Sclerotium rolfsii), and fusarium wilt (Fusarium oxysporum f. sp. lycopersici), and grafting with resistant rootstock has been proposed as a way to mitigate these issues. In the southeastern United States, where these pests are very common, using resistant rootstocks has been an effective Integrated Pest Management strategy to reduce RKNs (Rivard et al., 2010a), southern blight (Rivard et al., 2010a), fusarium wilt (Rivard and Louws, 2008), and verticillum wilt [ $\mathrm{Ver}$ ticillum dabliae (Louws et al., 2010)]; however, there is little information focused on grafting in production settings where less disease pressure exists, particularly in the central United States.

Rootstock selection is a key step in successful deployment of this technology as certain rootstocks may target specific diseases, abiotic stress, or overall yield benefits (Louws et al., 2010; Rivero et al., 2003). There are a number of rootstock options available to high tunnel growers in the United States, including interspecific hybrid rootstocks that may provide added vigor to the plant (Kubota et al., 2008; Louws et al., 2010). The crop performance and/or conferred disease-resistance characteristics of 'Maxifort' rootstock (De Ruiter Seeds, Bergschenhoek, The Netherlands) has been reported in North Carolina (Louws et al., 2010; Rivard and Louws, 2008), and this rootstock is very popular among growers using grafted plants throughout the United States. 'Trooper Lite' is an interspecific hybrid rootstock that was released into the U.S. market in 2010 and little has been reported about its overall vigor. Unfortunately, 'Trooper Lite' was pulled off the U.S. seed market in 2013 as it had inconsistent germination characteristics (Seedway, unpublished data).

Despite potential advantages and increasing grower interest, market availability of grafted tomato in the United States is currently limited. More than 40 million grafted tomato plants were imported annually from specialty nurseries in Canada and Mexico (Kubota et al., 2008). Recently, herbaceous grafting nurseries have begun to appear in the United States, but long-distance shipping and nurseries of this size have difficulty catering to the specialty requirements of small to midsize growers

\begin{tabular}{llll}
\hline $\begin{array}{l}\text { Units } \\
\begin{array}{l}\text { To convert U.S. to SI, } \\
\text { multiply by }\end{array}\end{array}$ & U.S. unit & SI unit & $\begin{array}{l}\text { To convert SI to U.S., } \\
\text { multiply by }\end{array}$ \\
\hline 0.4047 & $\mathrm{acre}(\mathrm{s})$ & $\mathrm{ha}$ & 2.4711 \\
0.3048 & $\mathrm{ft}$ & $\mathrm{m}$ & 3.2808 \\
2.54 & inch $(\mathrm{es})$ & $\mathrm{cm}$ & 0.3937 \\
1.1209 & $\mathrm{lb} / \mathrm{acre}$ & $\mathrm{kg} \cdot \mathrm{ha}^{-1}$ & 0.8922 \\
28.3495 & $\mathrm{oz}$ & $\mathrm{g}$ & 0.0353 \\
2.2417 & ton $(\mathrm{s}) / \mathrm{acre}$ & $\mathrm{t} \cdot \mathrm{ha}^{-1}$ & 0.4461 \\
$\left({ }^{\circ} \mathrm{F}-32\right) \div 1.8$ & $\mathrm{o} F$ & ${ }^{\circ} \mathrm{C}$ & $\left({ }^{\circ} \mathrm{C} \times 1.8\right)+32$
\end{tabular}


(Kubota et al., 2008). Growers can perform their own grafting (Rivard and Louws, 2011); however, management of grafted plants can be difficult.

We surveyed fruit and vegetable growers at a regional growers' conference (St. Joseph, MO) on their interest and usage of grafted plants. Of the 265 participants surveyed (65\% of which were growing in high tunnels), $19 \%$ were using grafted plants, $56 \%$ were interested in learning more, and $24 \%$ were not using grafted plants, but would like to. Interestingly, $47 \%$ of respondents indicated they would prefer to grow their own grafted plants, whereas $25 \%$ indicated they would prefer to purchase grafted plants (C.L. Rivard, unpublished data). These data highlight the potential impact that development of accessible propagation systems could have at overcoming barriers related to grafting in the central United States.

Finding a way to reduce the high humidity requirements of grafted seedlings immediately postgrafting would be extremely beneficial to facilitate onfarm grafting with limited greenhouse facilities. Grafted plants are placed inside "healing chambers" covered with polyethylene film and shadecloth to maintain high humidity and reduce light intensity directly after being grafted

\footnotetext{
We wish to sincerely thank Frank and Melanie Gieringer, Randy and Mary Clark, Nick and Loretta Rivard, Alicia Ellingsworth and Cultivate Kansas City, and the Olathe Horticulture Research and Extension Center.

Funding provided by the CERES Trust Research Initiative and the North Central Region Sustainable Agriculture Research and Education (NCR-SARE) program (GNCl2-162), and rootstock seed was donated by De Ruiter Seeds, Seedway, and BHN Seed, Inc. Technical support was provided by Mark Gawron, Annette Finkeldei, Laura Christensen, Vicente Mascote, Robbie Poulain, Aaron Yoder, and Jacob Chapman.

Mention of a trademark, proprietary product, or vendor does not constitute a guarantee or warranty of the product and does not imply its approval to the exclusion of other products or vendors that also may be suitable.

${ }^{1}$ Department of Horticulture, Forestry, and Recreation Resources, Kansas State University, Manhattan, KS 66506

${ }^{2}$ Department of Plant Pathology, Kansas State University, Manhattan, KS 66506

${ }^{3}$ Kansas State University Olathe Horticulture Research and Extension Center, Olathe, KS 66061

${ }^{4}$ Graduate Research Assistant

${ }^{5}$ Associate Professor

${ }^{6}$ Professor

${ }^{7}$ Assistant Professor
}

${ }^{8}$ Corresponding author. E-mail: crivard@ksu.edu.
(Masterson et al., 2016; Rivard and Louws, 2011). However, healing chambers built inside of greenhouses that do not have cooling equipment can become excessively hot, leading to plant wilting and death. Healing chambers also add to the cost of producing a grafted transplant, as they require additional materials and labor for management (Rivard et al., 2010b). Reducing leaf area could subsequently reduce transpiration and therefore reduce the need for intensive management of relative humidity during graft union healing. Leaf removal is recommended for the cleft and splice grafting method in an extension bulletin for tomato (Bumgarner and Kleinhenz, 2014). Furthermore, recent studies with leaf removal have shown that it can increase grafting success (Masterson et al., 2016).

In addition to reducing water stress, removing both the leaf and apical meristem (SR) could result in a plant that has two "leaders," each of which grows from the two cotyledon nodes. In the study by Masterson et al. (2016), using the SR method did not increase or penalize grafting success in various healing chamber environments. However, in an economics report (Rivard et al., 2010b), a propagation model was presented in which grafted plants were pinched to form two leaders $10 \mathrm{~d}$ postgrafting, and this was done at the request of the tomato grower who purchased the plants (Rivard et al., 2010b). Pruning grafted plants to two leaders is common with grafted plants, particularly when European string trellis systems are used in protected culture systems (Besri, 2003; Kubota et al., 2008). By removing the meristem after the grafted plant has been healed, additional regrowth time is required, and this can delay planting in the field/ greenhouse 10 to $14 \mathrm{~d}$ and/or slow early growth. If the meristem is removed during grafting, it could potentially advance the timeline toward a finished transplant by 10 to $14 \mathrm{~d}$.

By reducing leaf area via scion $S R$, reliance on the healing chamber for additional microclimate modification beyond greenhouse conditions could potentially be reduced or eliminated altogether. Additionally, this could be a valuable technique for propagators looking to grow plants that are pruned to two leaders. However, there is little information available as to whether scion SR will affect tomato yield and fruit marketability in a production setting. Therefore, this research had two primary objectives to 1) determine the efficacy of two rootstock cultivars at increasing tomato fruit yield in high tunnels in the central region of the United States and 2) test the effect of scion SR on tomato plant yield and biomass in a commercial production setting.

\section{Materials and methods}

Transplant PRODUCTION AND GRAFTING. All grafted and nongrafted transplants were produced at the Throckmorton Plant Sciences Center at Kansas State University (Manhat$\tan )$. Scion and nongrafted cultivars were BHN 589 (Siegers Seed Co., Holland, MI) and Cherokee Purple (Johnny's Selected Seeds, Winslow, $\mathrm{ME})$. 'BHN 589' is a determinate cultivar popular with high tunnel growers in the region and confers resistance to fusarium wilt, verticillium wilt (race 1), and RKNs. 'Cherokee Purple' is a commonly grown indeterminate heirloom cultivar with no known resistance to soilborne pathogens. 'Maxifort' (De Ruiter Seeds) and 'Trooper Lite' (Seedway, Hall, NY) were selected as rootstock cultivars for the grafted treatments. 'Maxifort' carries resistance against fusarium wilt (races 1 and 2), RKNs, Tobacco mosaic virus, and verticillium wilt (race 1 ). 'Trooper Lite' confers resistance to fusarium crown/root rot, fusarium wilt (race 2), Tomato mosaic virus, RKNs, and corky root (Rhizomonas suberifaciens). In all trials, all plants were monitored visually biweekly for soilborne disease incidence as well as severity to assess disease pressure from rootinfecting pathogens. Roots were also examined at the end of the trials to control for the presence of RKNs. Our goal was to evaluate rootstocks under little disease pressure so trials were not placed in areas that had a history of soilborne disease epidemics.

In all trials, a nongrafted control treatment was included as a standard comparison. All grafted treatments were grafted using the tube-grafting technique also known as splice grafting (Bumgarner and Kleinhenz, 2014; Oda, 1995; Rivard and Louws, 2011). Rootstock and scion seedling stems were cut and held together with a silicon clip (Hydro-Gardens, Colorado Springs, CO) at the two to four true leaf stage. In the standard method, 
no leaves were removed from the scion during the grafting process. We used the SR method, which consisted of removing the entire apical meristem and all true leaves from the scion at the time of grafting 1 to $2 \mathrm{~cm}$ above the cotyledon leaf nodes. The remaining scion tissue in the SR method consisted of a stem and two cotyledon leaves (with axillary buds for two leaders to develop). The rest of the process was the same as the standard tube-grafting method (Fig. 1). All grafted seedlings were subsequently placed inside a healing chamber with a polyethylene film covering, $55 \%$ shadecloth, and a supplemental cool-mist humidifier as described in Rivard and Louws (2011). Following graft union formation, $\approx 10 \mathrm{~d}$ after grafting, all tomato seedlings were removed from the healing chamber and grown in the greenhouse for $\approx 14 \mathrm{~d}$ before transplanting.

EXPERIMENTAL DESIGN AND DATA COLlection. A total of six experiments were conducted at four sites in 2011 and 2012. All six trials contained five identical rootstock/grafting method treatments, and were planted in a randomized complete block design with four replications. Five trials were located in high tunnels. Treatments included nongrafted 'BHN 589', 'BHN 589' grafted onto 'Maxifort' using the standard method, 'BHN 589' grafted onto 'Maxifort' rootstock with the SR technique, 'BHN 589' grafted onto 'Trooper Lite' rootstock, and 'BHN 589' grafted onto 'Trooper Lite' rootstock with the SR technique. The Reno County trial had

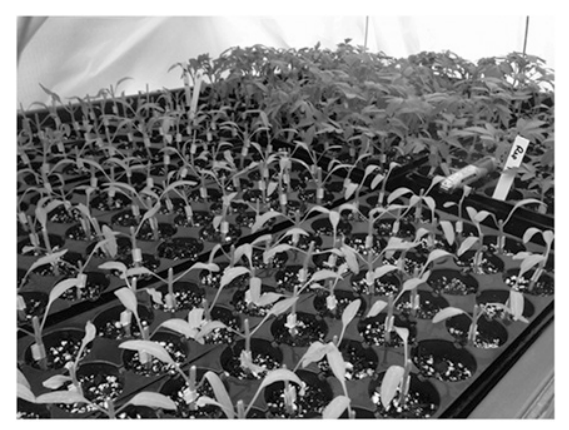

Fig. 1. Grafted tomato seedlings exhibiting the two grafting techniques-the shoot removal (SR) method (foreground) and standard tube-grafting method (background) inside of a healing chamber. Grafted seedlings were kept inside a chamber with $80 \%$ to $95 \%$ relative humidity for 7-9 d after grafting. the same rootstock/grafting method treatments, but used an heirloom scion 'Cherokee Purple' instead of 'BHN 589', and was grown in the open field. Each of the three on-farm cooperators marketed tomato fruit through farmers' markets. Therefore, all tomato fruit were harvested and graded as marketable or nonmarketable based on onfarm standards including presence of fruit diseases, blossom end rot, and/or pest damage. Fruit weight and number were recorded for each grade and for each plot. All fruit larger than 2 inches were harvested at the end of each growing season and included in total yield (total yield $=$ marketable + cull fruit). Vegetative growth (shoot biomass) was collected from one centrally located plant per plot at the end of the trials. Samples were dried at $70{ }^{\circ} \mathrm{C}$ for at least $96 \mathrm{~h}$ and weighed.

OLATHE HORTICULTURE RESEARCH AND EXTENSION CENTER TRIALS. High tunnel trials were conducted in 2011 and 2012 at the Kansas State University Olathe Horticulture Research and Extension Center (OHREC) located in Johnson County (lat. $38.884347^{\circ} \mathrm{N}$, long. $\left.94.993426^{\circ} \mathrm{W}\right)$. The soil type at this location was a Chase silt loam $(\mathrm{pH}=$ 6.3). This research trial was conducted within the central two rows of a three season, single-bay high tunnel (Haygrove, Ledbury, UK) measuring at $24 \times 200 \mathrm{ft}$. Two replications were planted within each of the two $120-\mathrm{ft}$ rows. 'BHN 589' was used as a nongrafted control and as scion for the grafted treatments. Each plot had seven plants in 2011 and six plants in 2012 . The five treatments were randomly assigned to $10.5-\mathrm{ft}$ plots. Cultural methods were consistent with commercial organic tomato production (O'Connell et al., 2012; Rivard et al., 2010a). In-row plants spacings were at 18 inches and rows were $5 \mathrm{ft}$ apart. Pelletized organic poultry manure (Chickity Doo-Doo ${ }^{\mathrm{TM}}$, Lake Mills, WI) was applied at a rate of $100 \mathrm{lb} /$ acre nitrogen $(\mathrm{N})$ at planting and water was applied throughout the growing season by drip irrigation. Weeds were suppressed via woven fabric mulch and plastic mulch in 2011 and 2012, respectively, and plants were trained in to a stake-and-weave vertical trellis system.

The OHREC trials were planted on 12 May 2011 and 23 Apr. 2012. All fruit that showed any sign of ripening (red color) were harvested. In 2011 , harvests occurred on 13, 19, and 26 July; 2, 9, 16, 23, and 30 Aug.; 6, 13, 20, and 27 Sept.; and 4 and 11 Oct. In 2012, harvest dates were on 19 and 26 June; 3, 10, 12, 16,24 , and 30 July; $7,14,21$, and 28 Aug.; 4, 12, 18, and 29 Sept.; and 5 Oct.

Johnson County ON-FARM TRIALS. Trials were conducted in 2011 and 2012 at a commercial farm located in Johnson County, KS (lat. $38.76473^{\circ} \mathrm{N}$, long. $95.008022^{\circ} \mathrm{W}$ ), at Gieringer's Orchard. The soil type in this location consisted of Sibleyville loam $(\mathrm{pH}=7.7)$. The trial was conducted in a $30 \times 96-\mathrm{ft}$, gothic-arch high tunnel annually planted entirely with tomato plants. This farm used composted cattle manure for fertility (2-inch application and incorporation before planting), but pest management was performed conventionally, with a fungicide application administered after transplanting and conventional insecticides applied as needed. 'BHN 589' was used as a nongrafted control and as scion for the grafted treatments. The trial occupied the inner four rows of the high tunnel, which had eight rows total. The four replications were planted within each 62 -ft row that was centrally located within the tunnel and included one replication per row. Each of the five treatments was randomly assigned to 10-ft length plots within each of the four blocks. Every plot contained five plants with in-row spacings at 24 inches apart and row spacings at $3.5 \mathrm{ft}$. Water was applied through drip irrigation beneath fabric mulch, which suppressed weeds. Tomato plants were trained into a modified stake-andweave trellis system with 1 -inch plastic plant clips (Hydro-Gardens) used to hold vines to the string trellis, which was made from wooden stakes and string. All treatments were transplanted into the high tunnel on 25 Apr. 2011 and 21 Mar. 2012. All fruit that showed any sign of ripening were harvested. Fruit were harvested on 13, 16,19 , and 26 July; 2, 9, 16, 23, and 30 Aug.; 6, 13, 20, and 27 Sept.; and 4, 11 , and 18 Oct. 2011. In 2012, harvests occurred on 11,19 , and 26 June; $3,10,17,24$, and 30 July; 7, 14, 21, and 28 Aug.; as well as 4 and 7 Sept.

Wyandotte County on-Farm TRIAL. A trial was conducted in 2012 at the Gibbs Road farm location of Cultivate Kansas City, a non-for-profit 
urban farming organization in Wyandotte County, KS (lat. $39.057955^{\circ} \mathrm{N}$, long. $94.678209^{\circ} \mathrm{W}$ ). The soil type in this location is composed of a mixture of both Lagoda silt loam and Marshall silt loam $(\mathrm{pH}=6.2)$. The trial was conducted in a $24 \times 96-\mathrm{ft}$ homemade quonset-style high tunnel that undergoes seasonal crop rotations. 'BHN 589 ' was used as a nongrafted control and as scion for the grafted treatments, and this trial was grown under certified organic production. The four replications were located in the two central, 88 -ft-long rows that were centrally located within the row. Each plot contained five plants with in-row spacings at 18 inches apart and row spacings at $5 \mathrm{ft}$. Pelletized organic poultry manure (Chickity Doo-Doo ${ }^{\mathrm{TM}}$ ) was applied at a rate of $100 \mathrm{lb} /$ acre $\mathrm{N}$ at planting and water was applied throughout the growing season by drip irrigation. Straw mulch was applied and tomato vines were trained in to a stake-and-weave system. All treatments were transplanted into the high tunnel on 28 Mar. Fruit were harvested at the red-ripe stage. Fruit harvests occurred on $15,18,25$, and 28 June; $2,3,6,9,13,16,23,27$, and 30 July; and on 2, 6, 10, 17, 21, 24, and 30 Aug.

Reno County ON-FARM TRIAL. This trial was conducted during 2012 at a small-acreage, diversified farm located in Reno County, KS (lat. $38.094^{\circ} \mathrm{N}$, long. $97.7413^{\circ} \mathrm{W}$ ). Soils consisted of Pratt-Turon fine sands $(\mathrm{pH}=5.8)$. The trial was located in four 72 -ft rows and was grown in the open field. It was managed organically, but was not certified organic. 'Cherokee Purple' was used as the nongrafted control and as scion in the grafted treatments. Composted sheep manure that was produced on-farm was used for fertility, as is the typical on-farm practice. About 2 inches was applied to the entire field and incorporated before planting. Vines were trellised using 24-inchdiameter $\times 6$-ft-tall, cylindrical tomato cages made from metal wire fencing. Every plot contained four plants with in-row spacings at $3 \mathrm{ft}$ apart and row spacings at $6 \mathrm{ft}$. Each replication was planted in a $60-\mathrm{ft}$ row with a total of four rows. Water was applied through drip irrigation, and straw mulch was applied for weed suppression. All treatments were transplanted into the field on 20 Apr. Fruit were harvested at the red-ripe stage. Harvesting occurred on 2, 9, 12, 15, $18,20,23,25,29$, and 31 July; $2,5,9$, 12, 16, and 20 Aug.; 7,16 , and 21 Sept.; and finally on 12 Oct.

Statistical analysis. Significant year $\times$ treatment and location $x$ treatment interactions occurred when the data were combined. Therefore, the data from each location/year were treated similarly but were analyzed independently. All data were analyzed in SPSS (version 15.0; IBM, Armonk, $\mathrm{NY}$ ) and showed no significant deviation from variance homogeneity; additionally, skewness and kurtosis statistics concluded yield and biomass data as about normal. Analysis of variance was used to determine separation of the treatment effects (PlotIt; Scientific Programming Enterprises, Haslett, MI), and where significant effects were identified, a mean separation test was carried out using an F-protected least significant difference test.

\section{Results}

IMPACT OF ROOTSTOCK AND GRAFTING METHOD ON FRUIT YIELD. In the OHREC trials (Tables 1 and 2), there was no evidence of soilborne disease pressure in either year. Standard grafting with 'Maxifort' and 'Trooper Lite' rootstocks significantly increased yield compared with nongrafted plants $(P<0.05)$. Total yield increases ranged from $41 \%$ to $44 \%$, and $57 \%$ to $99 \%$ in 2011 and 2012 , respectively. Fruit size and number of grafted treatments were significantly affected $(P<0.05)$ compared with the control plots with the exception of total fruit number in 2012. Compared with the nongrafted control, average total and marketable fruit size was increased with the implementation of both standard and SR grafting on 'Trooper Lite'. Average total and marketable fruit size was increased with both standard and SR grafting on 'Maxifort' in 2012 but with SR grafting on 'Maxifort' in 2012. In 2011, percent marketability based on both weight and number was not significantly affected by rootstock and/or grafting method (Table 1). In 2012, nongrafted plants produced significantly less marketable fruit (Table 2; $P<0.05)$.

At the Johnson County on-farm location, some disease pressure was evident in both years, but the severity was very low and not enough to warrant control methods by the grower. Verticillium wilt incidence was $11 \%$ across the entire trial in 2011 and $5 \%$ in 2012 . No treatment effects were seen related to incidence or severity of the disease. Significant increases in yield were seen in 2011 and 2012 using both standard and SR grafting on 'Maxifort' and 'Trooper Lite' rootstocks, but the benefit of grafting was much more dramatic in 2011 (Tables 3 and 4). In 2011, increases in marketable and total

Table 1. Tomato fruit yield and marketability of grafted and nongrafted 'BHN 589' grown using organic practices in a high tunnel at the Olathe Horticultural Research and Extension Center, Olathe, KS, in 2011.

\begin{tabular}{|c|c|c|c|c|c|c|c|c|}
\hline \multirow[b]{2}{*}{ Treatment $^{\mathrm{z}}$} & \multicolumn{3}{|c|}{ Marketable fruit yield } & \multicolumn{3}{|c|}{ Total fruit yield ${ }^{\mathrm{y}}$} & \multicolumn{2}{|c|}{ Marketable (\%) } \\
\hline & $\mathrm{Wt}\left(\mathrm{t} \cdot \mathrm{ha}^{-1}\right)$ & Size $(\mathrm{g})$ & No. $(1,000 / \mathrm{ha})$ & $\mathrm{Wt}\left(\mathrm{t} \cdot \mathrm{ha}^{-1}\right)$ & Size $(\mathrm{g})$ & No. $(1,000 / \mathrm{ha})$ & Wt & No. \\
\hline Nongrafted & $94.0 \mathrm{a}^{\mathrm{x}}$ & $152 \mathrm{a}$ & $615.6 \mathrm{a}$ & $108.8 \mathrm{a}$ & $146 \mathrm{a}$ & $745.3 \mathrm{a}$ & 86.2 & 82.6 \\
\hline 'Maxifort' (SR)w & $125.7 \mathrm{ab}$ & $170 \mathrm{ab}$ & $739.1 \mathrm{ab}$ & $144.4 \mathrm{~b}$ & $165 \mathrm{~b}$ & $877.0 \mathrm{ab}$ & 87.1 & 84.3 \\
\hline 'Trooper Lite' (standard) & $135.6 \mathrm{~b}$ & $174 \mathrm{~b}$ & $778.1 \mathrm{ab}$ & $153.9 \mathrm{~b}$ & $169 \mathrm{~b}$ & $907.2 \mathrm{ab}$ & 87.8 & 85.5 \\
\hline 'Trooper Lite' (SR) & $120.9 \mathrm{ab}$ & $176 \mathrm{~b}$ & $686.8 \mathrm{ab}$ & $136.9 \mathrm{ab}$ & $171 \mathrm{~b}$ & $800.6 \mathrm{ab}$ & 88.3 & 85.7 \\
\hline
\end{tabular}

${ }^{z}$ The experiment was set up in a randomized complete block design with four replications and four plants per treatment per block. Plants were grown using metal cages for a vertical trellis system and hay mulch with drip irrigation.

yAll tomato fruit were harvested and graded as marketable or nonmarketable based on on-farm standards including presence of fruit diseases, blossom end rot, and/or pest damage. Percent marketability was determined by dividing the marketable yield (weight, size, number) by the total yield (weight, size, number).

${ }^{x}$ Values followed by the same letter in the same column are not significantly different according to a protected Tukey's $\mathrm{w}$ procedure $(\propto=0.05) ; \mathrm{t} \cdot \mathrm{ha}{ }^{-1}=0.4461$ tons $/$ acre, $\mathrm{l} \mathrm{g}=0.0353 \mathrm{oz}, \mathrm{l}$ fruit/ha $=0.4047$ fruit/acre.

whoot removal: All true leaves and apical meristem of scion tissue were removed on grafting, leaving behind stem and two cotyledon leaves. 
fruit yield for all grafted treatments were $98 \%$ to $126 \%$ greater than the nongrafted control plots $(P<0.05)$. In contrast, total and marketable fruit yield increases in 2012 ranged from $18 \%$ to $25 \%$ but were still statistically significant compared with nongrafts (Table $4 ; P<0.05$ ). Both standard and SR grafting on both rootstocks significantly increased fruit size and number in 2011 and fruit number in 2012 compared with the nongrafted controls (Tables 3 and 4; $P<0.05)$. Fruit marketability was significantly greater in 2011 with both SR and standard grafting on 'Maxifort' and 'Trooper Lite' rootstocks and were greater in 2012 when calculated by weight (Table $4 ; P<0.05$ ).

In the Wyandotte County onfarm trial, there was no evidence of vascular wilt or nematode diseases. However, there was a nongrafted plant that died as a result of infection by timber rot (Sclerotinia sclerotiorum), constituting $1 \%$ of the total trial. No statistically significant differences in marketable or total yield between treatments were seen (Table 5). However, yield increases ranged from $21 \%$ to $30 \%$ compared with the control. Plants grafted with 'Maxifort' rootstock had significantly greater fruit number $(P<0.05)$, but average fruit size was unaffected. It is not clear why statistically significant yield

Table 2. Tomato fruit yield and marketability of grafted and nongrafted 'BHN 589' grown using organic practices in a high tunnel at the Olathe Horticultural Research and Extension Center, Olathe, KS, in 2012.

\begin{tabular}{|c|c|c|c|c|c|c|c|c|}
\hline \multirow[b]{2}{*}{ Treatment $^{z}$} & \multicolumn{3}{|c|}{ Marketable fruit yield ${ }^{y}$} & \multicolumn{3}{|c|}{ Total fruit yield ${ }^{y}$} & \multicolumn{2}{|c|}{ Marketable (\%) $)^{\mathrm{y}}$} \\
\hline & $\overline{W t}\left(\mathrm{t} \cdot h \mathrm{a}^{-1}\right)$ & Size (g) & No. $(1,000 / \mathrm{ha})$ & $\overline{W t}\left(\mathrm{t} \cdot h \mathbf{a}^{-1}\right)$ & Size $(g)$ & No. $(1,000 / \mathrm{ha})$ & $\mathrm{Wt}$ & No. \\
\hline Jon & $81.1 \mathrm{a}^{\mathrm{x}}$ & $118 \mathrm{a}$ & $697.9 \mathrm{a}$ & $116.0 \mathrm{a}$ & $108 \mathrm{a}$ & $1,078.8 \mathrm{a}$ & 75.8 & $71.0 \mathrm{a}$ \\
\hline (standard) & $150.6 \mathrm{~b}$ & $150 \mathrm{~b}$ & $1,002.8 \mathrm{~b}$ & $182.0 \mathrm{~b}$ & 143 & $1,275.5 \mathrm{a}$ & $87.5 \mathrm{bc}$ & $84.3 \mathrm{~b}$ \\
\hline 'Maxifort' (SR)w & $153.0 \mathrm{~b}$ & $165 \mathrm{~b}$ & $913.1 \mathrm{ab}$ & $190.2 \mathrm{~b}$ & $157 \mathrm{~b}$ & $1,196.0 \mathrm{a}$ & $85.4 \mathrm{~b}$ & $81.6 \mathrm{~b}$ \\
\hline 'Trooper Lite' (standard) & $161.6 \mathrm{~b}$ & $155 \mathrm{~b}$ & $1,041.7 \mathrm{~b}$ & $189.0 \mathrm{~b}$ & $150 \mathrm{~b}$ & $1,255.2 \mathrm{a}$ & $91.6 \mathrm{c}$ & $89.5 \mathrm{~b}$ \\
\hline 'Trooper Lite' (SR) & $147.8 \mathrm{~b}$ & $157 \mathrm{~b}$ & $944.8 \mathrm{ab}$ & $181.8 \mathrm{~b}$ & $149 \mathrm{~b}$ & $1,223.5 \mathrm{a}$ & $88.9 \mathrm{bc}$ & $85.2 \mathrm{~b}$ \\
\hline
\end{tabular}

${ }^{2}$ The experiment was set up in a randomized complete block design with four replications and four plants per treatment per block. Plants were grown using metal cages for a vertical trellis system and hay mulch with drip irrigation.

yAll tomato fruit were harvested and graded as marketable or nonmarketable based on on-farm standards including presence of fruit diseases, blossom end rot, and/or pest damage. Percent marketability was determined by dividing the marketable yield (weight, size, number) by the total yield (weight, size, number).

${ }^{x}$ Values followed by the same letter in the same column are not significantly different according to a protected Tukey's $\mathrm{w}$ procedure $(\propto=0.05) ; \mathrm{t} \cdot \mathrm{ha}{ }^{-1}=0.4461$ tons $/$ acre, $\mathrm{l} \mathrm{g}=0.0353 \mathrm{oz}, \mathrm{l}$ fruit/ha $=0.4047$ fruit/acre.

whoot removal: All true leaves and apical meristem of scion tissue were removed on grafting, leaving behind stem and two cotyledon leaves.

Table 3. Tomato fruit yield and marketability of grafted and nongrafted 'BHN 589' grown using conventional practices in a high tunnel at a commercial farm in Johnson County, KS, in 2011.

\begin{tabular}{|c|c|c|c|c|c|c|c|c|}
\hline \multirow[b]{2}{*}{ Treatment $^{\mathrm{z}}$} & \multicolumn{3}{|c|}{ Marketable fruit yield ${ }^{y}$} & \multicolumn{3}{|c|}{ Total fruit yield ${ }^{y}$} & \multicolumn{2}{|c|}{ Marketable $(\%)^{\mathrm{y}}$} \\
\hline & $\overline{W t}\left(\mathrm{t} \cdot \mathrm{ha}^{-1}\right)$ & Size $(g)$ & No. $(1,000 /$ ha $)$ & $\overline{\mathrm{Wt}\left(\mathrm{t} \cdot \mathrm{ha}^{-1}\right)}$ & Size $(g)$ & No. $(1,000 /$ ha $)$ & Wt & No. \\
\hline Nongrafted & $68.8 \mathrm{a}^{\mathrm{x}}$ & $123 \mathrm{a}$ & $558,3 \mathrm{a}$ & $78.1 \mathrm{a}$ & $117 \mathrm{a}$ & $665.2 \mathrm{a}$ & $87.7 \mathrm{a}$ & $83.6 \mathrm{a}$ \\
\hline 'Maxifort' (SR)w & $134.2 \mathrm{bc}$ & $154 \mathrm{~b}$ & $876.2 \mathrm{~b}$ & $139.3 \mathrm{bc}$ & $151 \mathrm{~b}$ & $925.7 \mathrm{abc}$ & $96.4 \mathrm{~b}$ & $94.6 \mathrm{~b}$ \\
\hline 'Trooper Lite' (standard) & $149.5 \mathrm{c}$ & $145 \mathrm{~b}$ & $1,039.1 \mathrm{~b}$ & $154.7 \mathrm{c}$ & $140 \mathrm{~b}$ & $1,116.6 \mathrm{c}$ & $96.6 \mathrm{~b}$ & $93.1 \mathrm{~b}$ \\
\hline 'Trooper Lite' (SR) & $111.9 \mathrm{~b}$ & $148 \mathrm{~b}$ & $757.1 \mathrm{ab}$ & $116.4 \mathrm{~b}$ & $144 \mathrm{~b}$ & $810.9 \mathrm{ab}$ & $96.1 \mathrm{~b}$ & $93.2 \mathrm{~b}$ \\
\hline
\end{tabular}

${ }^{2}$ The experiment was set up in a randomized complete block design with four replications and four plants per treatment per block. Plants were grown using metal cages for a vertical trellis system and hay mulch with drip irrigation.

yAll tomato fruit were harvested and graded as marketable or nonmarketable based on on-farm standards including presence of fruit diseases, blossom end rot, and/or pest damage. Percent marketability was determined by dividing the marketable yield (weight, size, number) by the total yield (weight, size, number).

${ }^{x}$ Values followed by the same letter in the same column are not significantly different according to a protected Tukey's $\mathrm{w}$ procedure $(\propto=0.05) ; \mathrm{t} \cdot \mathrm{ha}{ }^{-1}=0.4461$ tons $/$ acre, $\mathrm{lg}=0.0353 \mathrm{oz}, \mathrm{l}$ fruit $/ \mathrm{ha}=0.4047$ fruit/acre.

"Shoot removal: All true leaves and apical meristem of scion tissue were removed on grafting, leaving behind stem and two cotyledon leaves.

Table 4. Tomato fruit yield and marketability of grafted and nongrafted 'BHN 589' grown using conventional practices in a high tunnel at a commercial farm in Johnson County, KS, in 2012.

\begin{tabular}{|c|c|c|c|c|c|c|c|c|}
\hline \multirow[b]{2}{*}{ Treatment $^{\mathrm{z}}$} & \multicolumn{3}{|c|}{ Marketable fruit yield ${ }^{y}$} & \multicolumn{3}{|c|}{ Total fruit yield ${ }^{y}$} & \multicolumn{2}{|c|}{$\overline{\text { Marketable (\%) }}$} \\
\hline & $\overline{W t}\left(\mathrm{t} \cdot h \mathrm{a}^{-1}\right)$ & Size (g) & No. $(1,000 /$ ha $)$ & $\overline{W t}\left(\mathrm{t} \cdot \mathrm{ha}^{-1}\right)$ & Size $(g)$ & No. $(1,000 /$ ha $)$ & $\mathrm{Wt}$ & No. \\
\hline Nongrafted & $163.6 \mathrm{ab}^{\mathrm{x}}$ & 154 & $1,025.0 \mathrm{ab}$ & $171.7 \mathrm{ab}$ & 145 & $1,190.5 \mathrm{ab}$ & $95.3 \mathrm{~b}$ & 86.0 \\
\hline 'Maxifort' (SR)w & $183.2 \mathrm{bc}$ & 161 & $1,112.9 \mathrm{~b}$ & $201.7 \mathrm{bc}$ & 155 & $1,301.0 \mathrm{ab}$ & $90.1 \mathrm{a}$ & 86.3 \\
\hline 'Trooper Lite' (standard) & $192.9 \mathrm{bc}$ & 170 & $1,099.6 \mathrm{~b}$ & $208.3 \mathrm{c}$ & 158 & $1,315.3 \mathrm{~b}$ & $92.5 \mathrm{ab}$ & 84.0 \\
\hline 'Trooper Lite' (SR) & $142.2 \mathrm{a}$ & 160 & $868.8 \mathrm{a}$ & $157 \mathrm{a}$ & 146 & $1,083.6 \mathrm{a}$ & $90.5 \mathrm{a}$ & 81.0 \\
\hline
\end{tabular}

${ }^{2}$ The experiment was set up in a randomized complete block design with four replications and four plants per treatment per block. Plants were grown using metal cages for a vertical trellis system and hay mulch with drip irrigation.

${ }^{y}$ All tomato fruit were harvested and graded as marketable or nonmarketable based on on-farm standards including presence of fruit diseases, blossom end rot, and/or pest damage. Percent marketability was determined by dividing the marketable yield (weight, size, number) by the total yield (weight, size, number).

${ }^{x}$ Values followed by the same letter in the same column are not significantly different according to a protected Tukey's $\mathrm{w}$ procedure $(\propto=0.05) ; \mathrm{t} \cdot \mathrm{ha}^{-1}=0.446 \mathrm{l}$ tons $/ \mathrm{acre}$, $\mathrm{l} \mathrm{g}=0.0353 \mathrm{oz}, \mathrm{l}$ fruit $/ \mathrm{ha}=0.4047$ fruit/acre.

wShoot removal: All true leaves and apical meristem of scion tissue were removed on grafting, leaving behind stem and two cotyledon leaves. 
effects were not seen in this high tunnel study as compared with similar trials at OHREC and the Johnson County commercial farm.

In the Reno County on-farm trial, there was some pressure from RKNs, which is typical for the geographic area and soil types prevalent in the region. We rated $\mathrm{RKN}$ according to a 1 to 10 scale developed by Bridge and Page (1980). The average RKN rating across the entire trial was 4.33 and there were not significant effects among the treatments (data not shown). The top performing treatments in regard to final total and marketable yield were grafted plants with SR during the grafting procedure (Table 6). However, yield of SR-grafted plants were not significantly different from plants grafted using the standard method. Plants grafted with 'Maxifort' that had shoots removed had the greatest marketable and total fruit size and plants grafted with 'Trooper Lite' had the lowest average fruit size, although it was not significantly different from the nongrafted control
$(P<0.05)$. Grafting had no statistically significant effect on marketability in this trial.

Cumulative Yield AND EARLY SEASON PRODUCTION. An important question concerning the utilization of plants that are grafted using the SR method is how this technique impacts early vs. midseason and late-season production. Therefore, total cumulative yield is presented in Figs. 2-4. At OHREC in 2011, 'Trooper Lite' provided the highest early season production, including treatments where the SR technique was performed. Conversely, SR'Maxifort' plants had lower early season yields and caught up with standard-grafted plants $90 \mathrm{~d}$ after planting (Fig. 2A). In 2012, early season yield was fairly similar across all treatments, but SR-'Trooper Lite' had lower cumulative yield than the other treatments until $70 \mathrm{~d}$ after planting when yields were comparable among all treatments (Fig. 2B). Similar to 2011 , the benefit of using the SR-'Maxifort' and SR-'Trooper Lite' plants in 2012 was not equal to the standard-grafted plants until $125 \mathrm{~d}$ after planting (Fig. 2B).

At the Johnson County on-farm location, both SR-grafted treatments showed a dramatic lag in yield as compared with standard-grafted plants in both years (Fig. 3A and B). Similarly to the OHREC trials, cumulative fruit yield increased among the SR-grafted plants during the midseason and late season (Fig. 3A), and no statistical differences were seen between the standard- and SR-grafted plants in 2011 (Table 3; $P<0.05$ ). In 2012, however, cumulative fruit yield of SRgrafted plants was not able to catch up to standard-grafted plants (Fig. 3B) and statistically significant differences were seen (Table 4 ). Interestingly, in the 2012 study, the nongrafted plants produced much greater yield early in the season and then provided little additional fruit production in the midseason and late season (Fig. 3B).

Figure 4 shows the cumulative yield data for the Wyandotte and Reno County on-farm trials. In the Wyandotte County study, a pronounced yield lag can be observed by the

Table 5. Tomato fruit yield and marketability of grafted and nongrafted 'BHN 589' grown in a certified organic high tunnel at a commercial farm in Wyandotte County, KS, in 2012.

\begin{tabular}{|c|c|c|c|c|c|c|c|c|}
\hline \multirow[b]{2}{*}{ Treatment $^{\mathrm{z}}$} & \multicolumn{3}{|c|}{ Marketable fruit yieldy } & \multicolumn{3}{|c|}{ Total fruit yieldy } & \multicolumn{2}{|c|}{ Marketable (\%) } \\
\hline & $\mathrm{Wt}\left(\mathrm{t} \cdot \mathrm{ha}^{-1}\right)$ & Size $(\mathrm{g})$ & No. $(1,000 / \mathrm{ha})$ & $\mathrm{Wt}\left(\mathrm{t} \cdot \mathrm{ha}^{-1}\right)$ & Size $(\mathrm{g})$ & No. $(1,000 / \mathrm{ha})$ & $\mathrm{Wt}$ & No. \\
\hline Nongrafted & 103.7 & 211 & $501.6 \mathrm{a}^{\mathrm{x}}$ & 118.0 & 179 & 770.0 & 87.8 & 65.1 \\
\hline 'Maxifort' (SR)w & 119.4 & 193 & $630.0 \mathrm{ab}$ & 143.5 & 174 & 820.5 & 83.2 & 76.8 \\
\hline 'Trooper Lite' (standard) & 125.6 & 182 & $701.1 \mathrm{ab}$ & 153.0 & 163 & 943.5 & 82.1 & 74.3 \\
\hline 'Trooper Lite' (SR) & 91.8 & 179 & $513.1 \mathrm{a}$ & 111.5 & 163 & 681.0 & 82.3 & 75.3 \\
\hline
\end{tabular}

${ }^{2}$ The experiment was set up in a randomized complete block design with four replications and four plants per treatment per block. Plants were grown using metal cages for a vertical trellis system and hay mulch with drip irrigation.

yAll tomato fruit were harvested and graded as marketable or nonmarketable based on on-farm standards including presence of fruit diseases, blossom end rot, and/or pest damage. Percent marketability was determined by dividing the marketable yield (weight, size, number) by the total yield (weight, size, number).

${ }^{x}$ Values followed by the same letter in the same column are not significantly different according to a protected Tukey's $\mathrm{w}$ procedure $(\propto=0.05) ; \mathrm{t} \cdot \mathrm{ha}{ }^{-1}=0.4461$ tons $/$ acre, $\mathrm{lg}=0.0353 \mathrm{oz}, \mathrm{l}$ fruit $/ \mathrm{ha}=0.4047$ fruit/acre.

wShoot removal: All true leaves and apical meristem of scion tissue were removed on grafting, leaving behind stem and two cotyledon leaves.

Table 6. Tomato fruit yield and marketability of grafted and nongrafted 'Cherokee Purple' grown using organic practices in an open field at a commercial farm in Reno County, KS, in 2012.

\begin{tabular}{|c|c|c|c|c|c|c|c|c|}
\hline \multirow[b]{2}{*}{ Treatment $^{\mathrm{z}}$} & \multicolumn{3}{|c|}{ Marketable fruit yield ${ }^{y}$} & \multicolumn{3}{|c|}{ Total fruit yield ${ }^{\mathrm{y}}$} & \multicolumn{2}{|c|}{ Marketable (\%) } \\
\hline & $\mathrm{Wt}\left(\mathrm{t} \cdot \mathrm{ha}^{-1}\right)$ & Size $(g)$ & No. $(1,000 / \mathrm{ha})$ & $\mathrm{Wt}\left(\mathrm{t} \cdot \mathrm{ha}^{-1}\right)$ & Size $(g)$ & No. $(1,000 /$ ha $)$ & $\mathrm{Wt}$ & No. \\
\hline Nongrafted & $30.8 \mathrm{a}^{\mathrm{x}}$ & $180 \mathrm{ab}$ & 173.2 & $45.7 \mathrm{a}$ & $171 \mathrm{a}$ & 268.0 & 65.5 & 62.8 \\
\hline 'Maxifort' (SR) ${ }^{\mathrm{w}}$ & $57.2 \mathrm{~b}$ & $202 \mathrm{~b}$ & 286.4 & $78.3 \mathrm{~b}$ & $197 \mathrm{~b}$ & 366.0 & 79.3 & 78.0 \\
\hline 'Trooper Lite' (standard) & $41.2 \mathrm{ab}$ & $167 \mathrm{a}$ & 244.0 & $57.5 \mathrm{ab}$ & $171 \mathrm{a}$ & 324.2 & 74.0 & 75.0 \\
\hline 'Trooper Lite' (SR) & $54.8 \mathrm{~b}$ & $185 \mathrm{ab}$ & 280.8 & $68.9 \mathrm{ab}$ & $192 \mathrm{ab}$ & 359.2 & 79.0 & 77.5 \\
\hline
\end{tabular}

${ }^{\mathrm{z}}$ The experiment was set up in a randomized complete block design with four replications and four plants per treatment per block. Plants were grown using metal cages for a vertical trellis system and hay mulch with drip irrigation.

yAll tomato fruit were harvested and graded as marketable or nonmarketable based on on-farm standards including presence of fruit diseases, blossom end rot, and/or pest damage. Percent marketability was determined by dividing the marketable yield (weight, size, number) by the total yield (weight, size, number).

${ }^{\mathrm{x}}$ Values followed by the same letter in the same column are not significantly different according to a protected Tukey's $\mathrm{w}$ procedure $(\propto=0.05) ; 1 \mathrm{t} \cdot \mathrm{ha}{ }^{-1}=0.4461$ tons $/$ acre, $\mathrm{lg}=0.0353 \mathrm{oz}, \mathrm{l}$ fruit/ha $=0.4047$ fruit/acre.

whhoot removal: All true leaves and apical meristem of scion tissue were removed on grafting, leaving behind stem and two cotyledon leaves. 

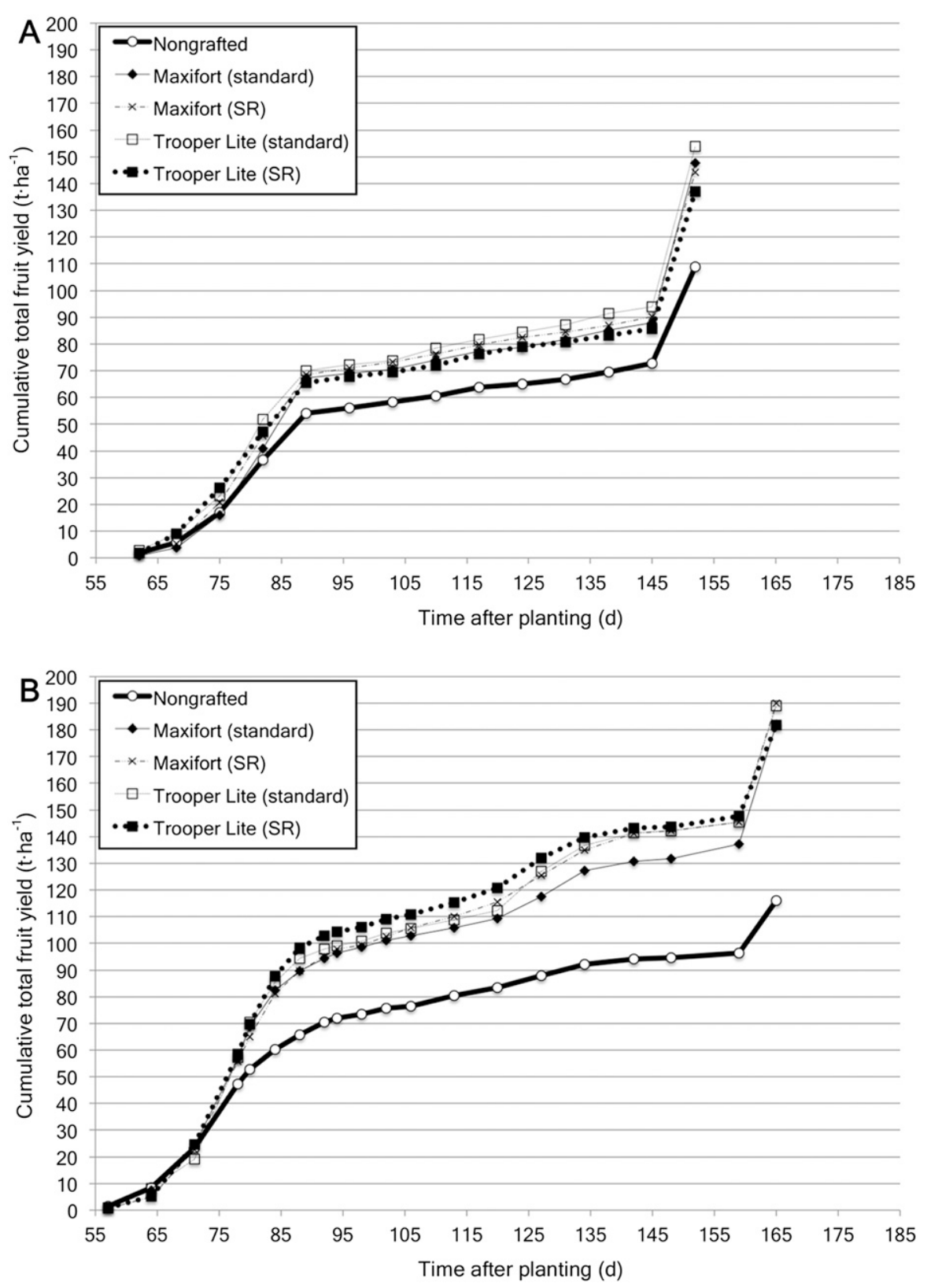

Fig. 2. Cumulative total fruit yield of grafted and nongrafted 'BHN 589' tomato grown using organic practices in a high tunnel at the Kansas State University Olathe Horticulture Research and Extension Center in Olanthe, KS, during (A) 2011 and (B) 2012 growing seasons. Grafting treatments include standard tubegrafting technique (standard) and when shoot/meristem was removed from scion during the grafting procedure [shoot removal (SR)] using two commercial rootstocks ('Maxifort' and 'Trooper Lite'); $1 \mathrm{t} \cdot \mathrm{ha}^{-1}=0.4461$ ton/acre.

SR-'Trooper Lite' and SR-'Maxifort' treatments (Fig. 4A). Plants grafted with the SR technique had lower yields than all other treatments until $100 \mathrm{~d}$ after planting and final total yield was statistically similar to nongrafted plants. The Reno County trial performed differently than the other trials in that early season yield was not penalized (Fig. 4B). In fact, the data for final yield suggest that these plants control in all four of these trials $(P<$ $0.05)$ 'Trooper Lite' increased shoot biomass compared with the nongrafted control in only one study (2012 Johnson County on-farm trial). Similarly, plants grafted with SR-'Maxifort' treatments had significantly increased biomass in two trials $(P<0.05)$, whereas SR-'Trooper Lite' plants had similar plant growth to nongrafted controls in all trials.

\section{Discussion}

GRAFTING FOR HIGH TUNNEL PRODUCTION IN THE CENTRAL UnITED STATES. Grafting with interspecific rootstock significantly increased yield in five of the six tomato trials reported here $(P<0.05)$ including four of the five the high tunnel trials. Yield increases ranged from $18 \%$ to $126 \%$ for standard-grafted plants compared with nongrafted controls. The average yield increase when 'Maxifort' rootstock was used was $53 \%$ across all the trials. Similarly, the average yield benefit with the use of 'Trooper Lite' rootstock was $51 \%$. These data indicate that both rootstocks were successful at increasing fruit yield for tomato growers in the central United States and were similar when compared with each other using the standard tubegrafting technique. It is not clear why the effect of grafting was so pronounced in 2011 as compared with 2012 at the Johnson County on-farm location. Marketable and total yields were particularly low for the nongrafted plants in the Johnson County on-farm trial in 2011 as compared with 2012 . These data suggest the ability of grafted plants to perform well during years with poor growing conditions for tomato production.

EFFECT OF SHOOT REMOVAL ON GRAFTED PLANT PERFORMANCE. The effect of SR on grafted plant performance was not as consistent as grafting across all six of the trials. However, some trends can be observed, particularly as fruit yield of grafted plants is related to rootstock vigor. Overall, the effect of SR reduced performance of the grafted plants as it relates to final plant yield (Tables 1-6). Across all six of the trials, observations can be made for both total and marketable fruit yield, comprising twelve comparisons in total. Out of the twelve comparisons, 'Maxifort' increased fruit yield in eight of these (Tables 1-4) and was not 

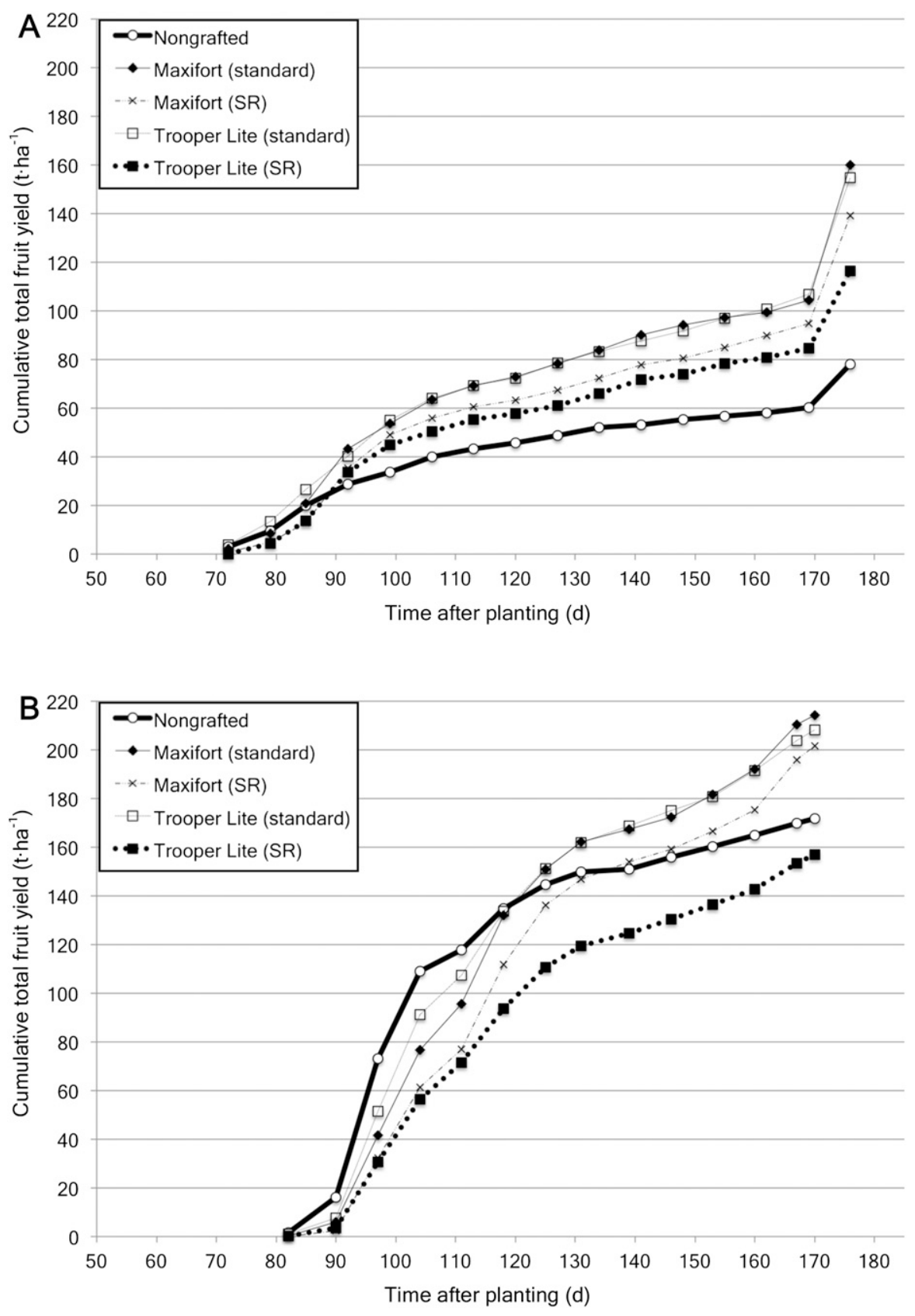

Fig. 3. Cumulative total fruit yield of grafted and nongrafted 'BHN 589' tomato grown using conventional practices in a high tunnel at a commercial farm in Johnson County, KS, during (A) 2011 and (B) 2012 growing seasons. Grafting treatments include standard tube-grafting technique (standard) and when shoot/ meristem was removed from scion during the grafting procedure [shoot removal (SR)] using two commercial rootstocks ('Maxifort' and 'Trooper Lite'); 1 t.ha ${ }^{-1}=0.4461$ ton $/$ acre.

significant at two locations in 2012 (Tables 5 and 6). Similarly, when 'Maxifort' was grafted using the SR technique, significant increases were seen in seven of the twelve comparisons for total and marketable fruit yield. When comparing 'Trooper Lite' in the same manner, significant yield increases were seen in seven of twelve comparisons for the standard grafting technique, but only five of the twelve comparisons for the SR-grafted plants $(P<0.05)$. Interestingly, in both years at the Johnson County on-farm trial site (Tables 3 and 4), SR-grafted 'Trooper Lite' had significantly lower fruit yield than plants grafted with 'Trooper Lite' using the standard method $(P<0.05)$, whereas all grafted plants (standard and SR method) with 'Maxifort' rootstock had statistically similar fruit yield. Although the pattern of statistical significance is not duplicated, this trend can be seen numerically in the 2011 OHREC and 2012 Wyandotte County on-farm high tunnel trials as well. These results suggest that 'Trooper Lite' was penalized by the SR technique. Furthermore, the SRgrafted plants with 'Trooper Lite' rootstock had statistically similar yield to the nongrafted plants in four of the five high tunnel trials.

One explanation for this poor response to the SR grafting method could be a lack of vigor by 'Trooper Lite' as compared with 'Maxifort'. The shoot biomass data from these trials indicate that 'Maxifort' increased overall plant vigor more consistently than 'Trooper Lite'. Removal of the shoot during the grafting procedure results in a smaller transplant at planting with fewer and/or smaller developed leaves. These plants are therefore required to grow faster to catch up to their counterparts grafted with the standard technique at the same time. Shoot biomass was significantly increased in four of the six trials by 'Maxifort' rootstock and only one of the six trials by 'Trooper Lite' rootstock (Table $7 ; P<0.05$ ) when the standard grafting technique was used. This indicates that 'Maxifort' increased plant vigor whereas 'Trooper Lite' did not. For future studies, a comparison of non- or self-grafted plants that have undergone the SR process would be advantageous for determining its effect on tomato yield.

Because SR-grafted plants may be smaller at the time of planting, this may reduce the early season yield as compared with plants with the standard grafting method. An examination of the cumulative yield curves indicate that although SR-grafted plants may perform similarly when final yield is tabulated at the end of the year, it could have negative effects on early and midseason production. Early season production is extremely important to growers, particularly those growing in high tunnels (Carey et al., 2009). Interestingly, in the Reno County study, SR did not penalize early season yield and the SRgrafted plants had the greatest final yield. It should be noted that in contrast to the other sites tested, this trial used an heirloom, indeterminate 

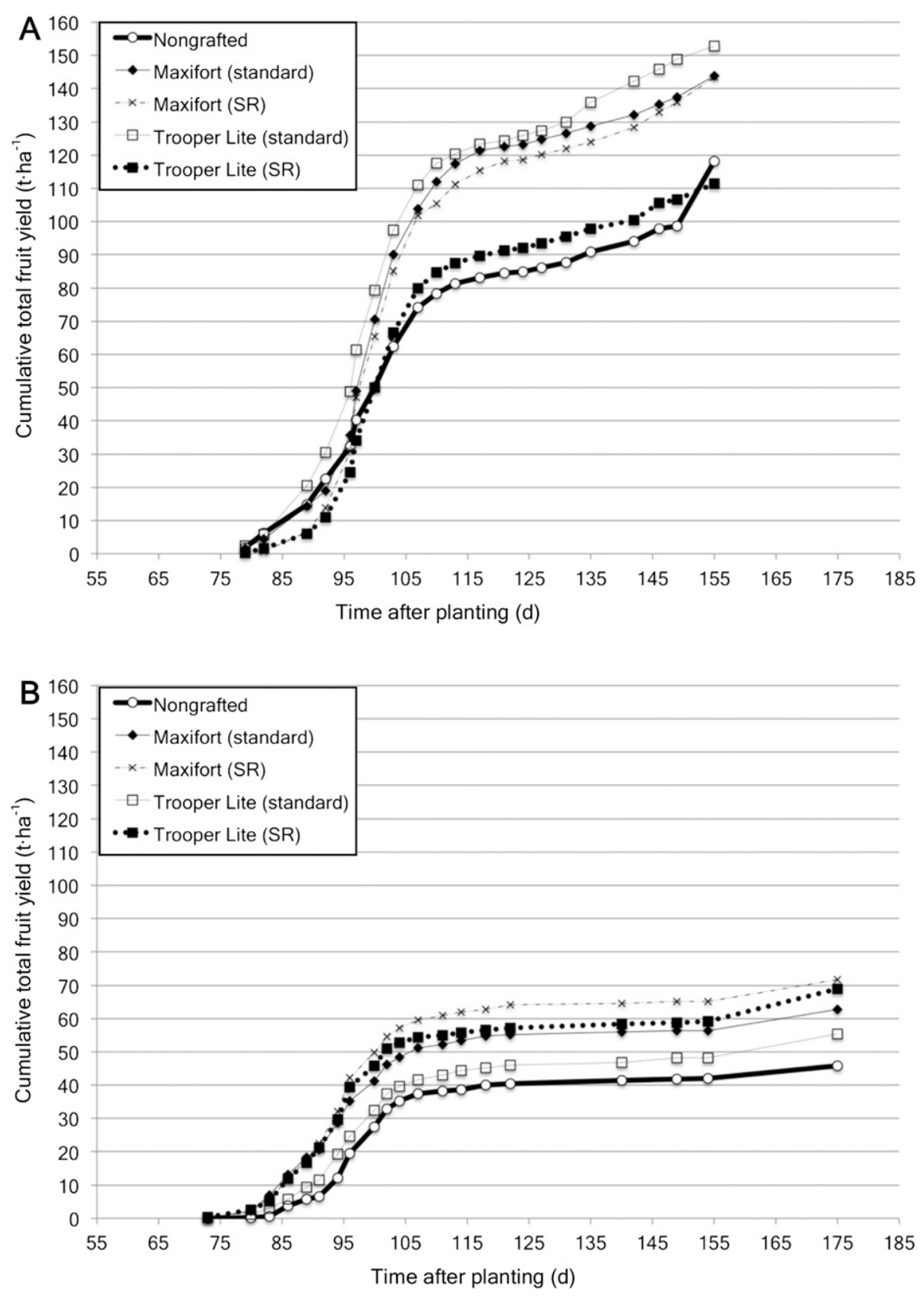

Fig. 4. Cumulative total fruit yield of grafted and nongrafted tomato grown using organic practices in (A) a high tunnel at a commercial farm in Wyandotte County, KS, and (B) an open field at a commercial farm in Reno County, KS, during 2012 growing season. Grafting treatments include standard tube-grafting technique (standard) and when shoot/meristem was removed from scion during the grafting procedure [shoot removal (SR)] using two commercial rootstocks ('Maxifort' and 'Trooper Lite'). Scion cultivar was BHN 589 and Cherokee Purple at Wyandotte and Reno County locations, respectively; $1 \mathrm{t} \cdot \mathrm{ha}^{-1}=0.4461$ ton/acre.

cultivar, and the plants were grown in cages at a much lower planting density and in the open field. It could be suggested that the added leader of the plant as a result of SR was successful at increasing leaf area and therefore overall crop vigor and yield. However, this system was only tested at one location and in one year so it is difficult to determine if the effect of the shoot grafting removal method is small-acreage growers in the central United States. Previous reports demonstrated that significant yield increases may occur in grafted cucurbit crops, when few biotic stressors are present (Ruiz and Romero, 1999; Yetisir and Sari, 2003). Our study suggests that grafting with interspecific hybrid rootstocks, 'Maxifort' and 'Trooper Lite', increases fruit yield for tomato when little disease pressure is evident in high tunnels, which are commonly used for tomato production on small farms (Carey et al., 2009). Both rootstocks conferred a significant increase in yield compared with the nongrafted plants when the standard tube-grafting method was used.

The effect of SR was less consistent across the six trials and seems to be affected by rootstock cultivar. Final yield was unaffected when 'Maxifort' rootstock was grafted using the SR technique as compared with 'Trooper Lite'. 'Maxifort' is an especially vigorous rootstock and has shown yield increases in previous studies (Rivard et al., 2010a), and particularly during the later parts of the season (Rivard and Louws, 2008). However, both rootstocks exhibited a lag in production during the early harvest period (up to $100 \mathrm{~d}$ after planting) when the SR method was used. Removing the shoot was observed to reduce early season plant growth especially in the first 2 to 3 weeks after transplanting (data not shown). This suggests that the required regrowth of the scion tissue after removing the shoots resulted in lower yields than standard grafting methods in our studies. One way to circumvent this problem would be to plant SR-grafted seedlings earlier, thereby giving them more time in the greenhouse to grow before planting. However, propagators that are catering to multiple markets may find it difficult to predict which customers will want grafted plants with one vs. two leaders and the cost of keeping them in the greenhouse can be important, depending on the availability of space (Rivard et al., 2010b). The added growth rate of the plants grafted with 'Maxifort' was probably able to compensate for the required regrowth needed for the removed shoots. These findings suggest that rootstock vigor is an important consideration for growers wishing to use the SR grafting method.

These data suggest that grafting is a highly advantageous technology 
Table 7. Shoot biomass of grafted and nongrafted tomato plants using two grafting methods and two rootstocks from six high tunnel and open-field trials in Kansas.

\begin{tabular}{|c|c|c|c|c|c|c|}
\hline \multirow[b]{3}{*}{ Treatment $^{\mathrm{z}}$} & \multicolumn{6}{|c|}{ Shoot biomass $(\mathrm{g})^{\mathrm{y}}$} \\
\hline & \multicolumn{2}{|c|}{ OHREC $^{x}$} & \multicolumn{2}{|c|}{ Johnson County $^{w}$} & \multirow{2}{*}{$\frac{\text { Wyandotte County }^{\mathrm{v}}}{2012}$} & \multirow{2}{*}{$\frac{\text { Reno County }^{\mathrm{u}}}{2012}$} \\
\hline & 2011 & 2012 & 2011 & 2012 & & \\
\hline Nongrafted & $408.8 \mathrm{a}^{\mathrm{t}}$ & $334.3 \mathrm{a}$ & $268.5 \mathrm{a}$ & $346.8 \mathrm{a}$ & 301.3 & $1,189.0$ \\
\hline 'Maxifort' (standard) & $577.8 \mathrm{~b}$ & $492.0 \mathrm{~b}$ & $470.3 \mathrm{~b}$ & $535.5 \mathrm{~b}$ & 536.3 & $1,132.5$ \\
\hline 'Maxifort' $(\mathrm{SR})^{\mathrm{s}}$ & $525.8 \mathrm{ab}$ & $480.8 \mathrm{~b}$ & $421.0 \mathrm{ab}$ & $588.5 \mathrm{~b}$ & 441.7 & $1,101.8$ \\
\hline 'Trooper Lite' (standard) & $370.8 \mathrm{a}$ & $455.8 \mathrm{ab}$ & $305.5 \mathrm{ab}$ & $496.0 \mathrm{~b}$ & 539.3 & $1,246.0$ \\
\hline
\end{tabular}

${ }^{2}$ The experiment was set up in a randomized complete block design with four replications and four plants per treatment per block. Plants were grown using metal cages for a vertical trellis system and hay mulch with drip irrigation.

${ }^{\mathrm{y}}$ Tomato shoot biomass was sampled at the last harvest date and dried at $158{ }^{\circ} \mathrm{F}\left(70.0{ }^{\circ} \mathrm{C}\right)$ for at least $96 \mathrm{~h} ; 1 \mathrm{~g}=0.0353 \mathrm{oz}$.

'Olathe Horticulture Research and Extension Center, Olathe, KS. Organic high tunnel trial with 'BHN 589' scion and for nongrafted control.

"Conventional high tunnel trial with 'BHN 589' scion and for nongrafted control.

'Organic high tunnel trial with 'BHN 589' scion and for nongrafted control.

"Organic open-field trial with 'Cherokee Purple' scion and for nongrafted control.

'Values followed by the same letter are not significantly different according to a protected Tukey's w procedure $(\propto=0.05)$.

shoot removal: All true leaves and apical meristem of scion tissue were removed on grafting, leaving behind stem and two cotyledon leaves.

for high tunnel growers in the central region of the United States. Grafting is a beneficial option in terms of yield for growers, but growers interested in on-farm grafting (as opposed to purchasing grafted plants) may discover many challenges related to grafted propagation. Therefore, simplified techniques that require less intensive management are critical for adoption of grafting for tomato growers. Although the SR technique may not be a consistent method in terms of tomato yield, it may be a valuable technique when used with certain rootstocks to boost yield and simplify the grafting procedure.

\section{Literature cited}

Besri, M. 2003. Tomato grafting as an alternative to methyl bromide in Morocco. 26 Mar. 2016. <http://mbao.org/2003/ $012 \% 20$ besrimgraftingmbao2003sd.pdf $>$.

Bridge, J. and S.L. Page. 1980. Estimation of root-knot nematode infestation levels on roots using a rating chart. Trop. Pest Mgt. 26:296-298.

Bumgarner, N.R. and M.D. Kleinhenz. 2014. Grafting guide-A pictorial guide to the cleft and splice graft methods. Ohio State Univ. Ohio Agr. Res. Dev. Ctr. Bul. 950.

Carey, E.E., L. Jett, W.J. Lamont, T.T. Nennich, M.D. Orzolek, and K.A. Williams. 2009. Horticultural crop production in high tunnels in the United States: A snapshot. HortTechnology 19:37-43.
Hunter, B., D. Drost, and B. Black. 2010. High tunnel tomato production. 2010. Utah State Univ. Coop. Ext. Hort. Bul. April 2010.

Kubota, C., M.A. McClure, N. KokalisBurelle, M.G. Bausher, and E.N. Rosskopf. 2008. Vegetable grafting: History, use, and current technology status in North America. HortScience 43:1664-1669.

Louws, F., C.L. Rivard, and C. Kubota. 2010. Grafting fruiting vegetables to manage soilborne pathogens, foliar pathogens, arthropods and weeds. Sci. Hort. 127:127-146.

Masterson, S.A., M.M. Kennelly, R.R. Janke, and C.L. Rivard. 2016. Microclimate and scion leaf removal to improve the success of grafted tomato seedlings. HortTechnology 26:261-269.

O'Connell, S., C.L. Rivard, M. Peet, C.D. Harlow, and F.J. Louws. 2012. High tunnel and field production of organic heirloom tomatoes: Yield, fruit quality, disease, and microclimate. HortScience 47:1283-1290.

Oda, M. 1995. New grafting methods for fruit-bearing vegetables in Japan. Jpn Agr. Res. Qrtly. 29:187-194.

Rivard, C.L. and F.J. Louws. 2008. Grafting to manage soilborne diseases in heirloom tomato production. HortScience 43:2104-2111.

Rivard, C.L. and F.J. Louws. 2011. Tomato grafting: A new tool for disease resistance and increased productivity. Sustainable Agr.
Res. Educ. (SARE) Agr. Innovation Bul. Ser. SARE Publ. No. 12AGI2011.

Rivard, C.L., S. O'Connell, M.M. Peet, and F.J. Louws. 2010a. Grafting tomato with interspecific rootstock provides effective management against diseases caused by $S$. rolfsii and southern rootknot nematodes. Plant Dis. 94:10151021 .

Rivard, C.L., O. Sydorovych, S. O'Connell, M.M. Peet, and F.J. Louws. 2010b. An economic analysis of two grafted transplant production systems in the U.S. HortTechnology 20:794-803.

Rivero, R.M., J.M. Ruiz, and L. Romero. 2003. Role of grafting in horticultural plants under stress conditions. Food Agr. Environ. 1:70-74.

Ruiz, J.M. and L. Romero. 1999. Nitrogen efficiency and metabolism in grafted melon plants. Sci. Hort. 81:113-123.

U.S. Department of Agriculture. 2013. Environmental Quality Incentives ProgramSeasonal high tunnel initiative. 12 Feb. 2016. <http://www.nrcs.usda.gov/wps/ portal/nrcs/detailfull/national/programs/ ?cid=stelprdb1046250>.

Wells, O.S. 1991. Guidelines for using high tunnels for tomato production. Univ. New Hampshire Coop. Ext. Publ.

Wells, O.S. and J.B. Loy. 1993. Rowcovers and high tunnels enhance crop production in the northeastern United States. HortTechnology 3:92-95.

Yetisir, H. and N. Sari. 2003. Effect of different rootstock on plant growth, yield and quality of watermelon. Austral. J. Expt. Agr. 43:1269-1274. 